\title{
Critical Analysis of Corporate Social Responsibility Concept
}

\section{Jose G Vargas-Hernandez and Carlos Gustavo Montano Cruz}

University of Guadalajara, Mexico

*Corresponding author: Jose G Vargas-Hernandez, M.B.A, Ph.D., University Center for Economic and Managerial Sciences, University of Guadalajara, Periferico Norte 799 Edif. G.201-7, Nucleo Universitario Los Belenes, Zapopan, Jalisco, 45100, Mexico, Tel: +523337703340; E-mail: jvargas2006@gmail.com

Rec date: July 04, 2016; Acc date: Sep 13, 2016; Pub date: Sep 17, 2016

Copyright: ( 2016 Vargas-Hernandez JG, et al. This is an open-access article distributed under the terms of the Creative Commons Attribution License, which permits unrestricted use, distribution, and reproduction in any medium, provided the original author and source are credited

\begin{abstract}
This paper aims to critically analyze the concept of corporate responsibility. The analysis attempts to answer the following questions: Critically evaluate the concept of corporate social responsibility, discuss how corporate social responsibility reduces the social responsibility of consumers. The method is based on analysis of the literature review descriptive. We conclude that corporate social responsibility affects the social responsibility of the consumer to the extent that circumstances permit, positively or negatively.
\end{abstract}

Keywords: Social responsibility performance; Corporate social responsibility; Social responsibility of the consumer

\section{Introduction}

Corporate social responsibility (CSR), also called business social responsibility (BSR) is achieved when the company began a voluntary and active contribution to the social, environmental and economic improvement. This is in order to improve their competitive, valuesituation and value of the corporations. When a good performance of these three characteristics is achieved, it is known as the triple bottom line. This triple bottom is used for sustainable business and as the name implies, covers three dimensions: environmental, economic size and revenue statements. Triple bottom line performance is known through sustainability reporting and/or corporate social responsibility.

For the International Labor Organization [1], social responsibility of business is the set of actions that take into account the companies so that their activities have a positive impact on society and affirm their principles and values that they governed, both in their own internal methods and processes and in their relationship with the other actors. The Brazilian Ethos Company and Social Responsibility Institute [2], defines corporate social responsibility as a form of management that is defined by the ethical relationship between the company and the shareholders, and the establishment of business goals compatible with them, respecting diversity and promoting the reduction of social inequalities.

Milton Friedman [3], in his book Capitalism and Freedom wrote: It has gained acceptance the view that corporate officials and union leaders have a social responsibility that goes beyond serving the interests of its shareholders or members.

\section{Variables to measure the performance of social responsibility}

According to Alcabes [4], there are ten variables to measure the performance of a company in order to know how socially responsible are:

- Structures of payments for salaries: The employees of the organization representing the essence of the company. The greater the number of well-paid workers, the higher purchasing power and, consequently, the economic movement of the country will be encouraged.

- Generation or declining employment: It refers to acquisitions or mergers. It is estimated the total number of employees at the beginning of the year, plus the total of persons engaged in the same, minus the total of people who stopped working in the company.

- Preservation of the environment: The company calls itself from number 1 to 5 for the quality of the environment in the development of its operations. The degree of pollution in the air, water and soil as a result of their production processes and/or their waste is measured.

- Concern for occupational health of its personnel: It is measured by the number of diagnosed cases of occupational diseases in the period and the number of accidents attributable to failure of the means of prevention or protection.

- Level of customer satisfaction with the products or services of the company: An enterprise should measure the degree of acceptance of their products or services through the level of sales and growth curve over time. It should be clarified whether the market competition is high or there is oligopoly.

- Intensity of competition: It should be measured if there are in the market many or few competitors.

- Use of natural resources of the country or domestic inputs: This variable will explain how the organization contributes to the generation of jobs and foreign exchange savings for this domestic production must be competitive and required quality.

- Share of exports in total production value of the company: When exports contribute to national development, to job creation, the use of natural resources and domestic inputs.

- Net income as a percentage of shareholders' equity or the owners invested in the country. When a company dedicates a percentage of its profits to investment in its country of origin, the organization makes clear its commitment to national development.

- Contribution of the company works or actions for the benefit of national communities: This variable includes those direct actions or contributions from the company or works programs to benefit communities in the country. 
Page 2 of 3

\section{The relationship between corporate social responsibility and the responsibility of consumers}

CSR does not reduce the social responsibility of consumers; provided that the consumer is of a higher socioeconomic status. CSR reduces the social responsibility of consumers to the extent that campaigns are used to transmit values.

\section{Corporate social responsibility reduces the social responsibility of consumers}

In the case of Mexico, there are many campaigns for recycling to waste as little as possible to conserve water, reduce obesity, etc. Many programs in order to raise awareness among consumers about the social responsibility and the environment, taking the baton through advertising campaigns and they do to their products. When consumers buy a certain brand of yogurt that like for its taste, but also know that a certain amount of profits will go to protect the Lacandona jungle, they know they've helped the environment by simply having bought the product.

When the consumer accepts around out his/her change, i.e. donate cents he/she can spare, so the company that collects this change can help an association of children with cancer, he/she knows he/she has helped. When a Mexican television every year in December is asking the citizens to donate $\$ 10, \$ 20$ or $\$ 50$ for the foundation of this company can help children with disabilities; the person knows it has helped. This type of advertising campaigns has opted in what it is called marketing "light support".

The light aids are those actions taken through minimal effort, but it is known in advance that will help, through third parties, to the welfare of any human being, animal or the environment. It is very fashionable now with social networks, pointing to people who are believed is not socially responsible. Such as refining companies that dump their waste into rivers, lakes and seas. It is known that such actions are wrong, but simply point out; it gives us some peace of mind because it is known that people know they should condemn such acts.

That's why when it has been learned that there are companies that help humans to have a better quality of life, animals to avoid extinction or the environment for preservation, consumers buy products or donate money to a certain account number since they do not have the time to do it themselves, but they get the satisfaction of having helped. Arredondo, Maldonado and De la Garza [5] found in a group of consumers who even declare that corporate social responsibility is important, and they are price sensitive taking the only criterion that the product is cheap. Sierra and London [6] argue that companies should contribute to social objectives through the creation of wealth and equitable distribution.

For this reason, a socially responsible consumer is the one that links the impact of his decision according to what the company does with the product that decides to buy. An example is offering jam in Toks restaurants because it is a jam with 0.1 conservative; but the bottom line is not its low amount of sodium, but is made by rural communities in Guanajuato. Bhargava and Chakravarti [7] stated that the company adopts social causes in order for the consumers to compensate the consumer for its good intentions. UPS Company is known as a pioneer in using reusable envelopes Express delivery. These envelopes are made from $100 \%$ recycled fiber.

\section{Corporate social responsibility does not reduce the social responsibility of consumers}

According to Valor [8] there are three types of obstacles that must be overcome if a consumer wants to consume on a responsible way:

Motivational obstacles: Such as the perceived effectiveness and identity. The perceived effectiveness is a very interesting point as it relates to the way the decision to be socially responsible will have an impact or not. A clear example is the separation of waste. It was intended at the time that the waste should be separated into at least two types: organic and inorganic. Liquids and food debris deposited in organic waste, while the cardboard, bottles, and plastic bag was placed in inorganic. The plan sounded great, but it was soon discovered that the garbage collectors, to empty the waste returned to mixed waste, making the campaign was a disaster.

Cognitive barriers: Capture, process, store and retrieve brands through the information. How often campaigns that say something like listening to: "For every product you buy, a portion will be donated to: insert the social - Environmental benefit here". However, rarely explained the exact amount to be donated, the date of the donation and the foundation where the deposit of the proceeds will be held. This type of one-way communication is what often leads people to believe that these social - environmental campaigns really are not performed.

Barriers of conduct: Opportunity to find the right brand to purchase. This type of barrier is contrary to consumer loyalty to a brand. An example is when two products relatively cost the same. However, one drives a social or environmental campaign and the other not. Socially responsible consumer will choose one that is committed to these causes.

\section{Corporate social responsibility may or may not reduce the social responsibility of consumers.}

Scholder, Webb and Mohr [9], conclude that consumers respond positively to the efforts of social responsibility when they are driven by values and are strategic. However, they respond negatively when they are motivated by selfishness and interest of the affected. The Starbucks coffee Mexico and the National Institute of Older Persons implemented the program linking labor for older people, i.e. people older may work as bar tenders. This is an example of positive appreciation. The telethon is an example of negative perception, because it is well known that the revenue is deposited into a foundation as a single payment for the Televisa Company, this in order to avoid paying taxes, making "social aid" is in its own interest.

Rodriguez and Bustamante [10], state that a socially responsible consumer is one who anticipates the consequences of their decisions to buy and avoid causing harm to others. An example is when the consumer decides to purchase biodegradable toilet paper instead of the traditional as the biodegradable can be deposited directly on the potty toilet, making it degraded immediately and being kinder to the environment. Kohlberg [11] suggests that humans evolved in the course of life through three stages: conventional pre stage (focus on self); conventional stage (focusing on other close); stage post conventional (universal human perspective). Anderson et al. [12], state that a higher socioeconomic status, more socially conscious is consumer.

Interestingly, many of the biodegradable products are more expensive than traditional ones, as they need to be a more specialized way, so it is no surprise that statement. 
Citation: Vargas-Hernandez JG, Montano Cruz CG (2016) Critical Analysis of Corporate Social Responsibility Concept. J Socialomics 5: 181.

Page 3 of 3

\section{Conclusion}

It can be concluded that corporate social responsibility affects the social responsibility of the consumer to the extent that circumstances permit, positively or negatively. While human consumers currently live a stage to preserve the environment and help others, hardly they will do themselves. There are many excuses such as lack of time, lack of resources, and lack of information on the institutions that can help. That's why when companies and corporation's campaigns are promoting social and environmental well-being, consumers are delegated responsibility in exchange for buying their products and donate pennies left over them. Help is help, whether long or short.

But there is someone who is aware of the abuse of these companies wanting to move to the general public through the broadcast media of children with cancer, with psychomotor or brain disabilities. This type of mass deception makes people want to know nothing of this kind of light help or ecological or social aid campaigns, with a negative impact on the consumer.

This essay suggests that socially responsible companies will reduce or increase the social responsibility of the consumer in the following cases: If the consumer has enough money and can pay for an organic product knowing that it is more expensive than the polluter, it will be elected the ecological. When a product is promoting socially responsible campaigns and its competition does not, consumers will choose to which is conducting such a campaign. If the maturity, sustainable and sustained thinking of the individual allows the consumer to think as part of a social and future added, consumers will choose products with socially responsible campaigns. If the level of communication is bidirectional and management processes of social improvement are clear, the consumer will choose brands that operate under the criteria of socially responsible companies.

\section{References}

1. International Labour Organization (2007)

2. The Brazilian Ethos Company and Social Responsibility Institute (2011).

3. Friedman M (1962) Capitalism and freedom. Chicago: The University of Chicago Press 133.

4. Alcabes N (2005) The socially responsible company: A proposed selfevaluation. ESAN University. Peru.

5. Arredondo F, Maldonado V, De la Garza J (2010) Consumers and their buying decision making base on price and information about corporate social responsibility (CSR) Case study: Undergraduate students from a private university in Mexico. 26(117): 103-117

6. Sierra J, Londono D (2008) Potential ethical finance in generating new investment alternatives in Colombia. Administration notebooks 21(36): 183-220.

7. Bhargava S, Chakravarti A (2009) Empowered Consumers Benevolent Consumers? The Effects of Priming Power on the Appeal of Socially Responsible Products. Advances in Consumer Research - North American Conference Proceedings 36: 831-832.

8. Valor C (2008) Can Consumers Buy Responsibly? Analysis and Solutions for market failures. J consum policy 31: 315-332.

9. Scholder EP, Webb DJ, Mohr LA (2006) Building Corporate Associations: Consumer Attributions for Corporate Socially Responsible Programs. Journal of the Academy of Marketing Science 34(2): 147-157.

10. Rodriguez MP, Bustamante U (2008) Development of skills for ethical behaviour management: an approach of responsibility. Administration notebooks 21(35): 205-208.

11. Kohlberg L (1981) Essays on Moral Development, The Philosophy of Moral Development. CA: Harper \& Row. San Francisco, USA.

12. Anderson J, Thomas W, Cunningham WH (1972) The Socially Conscious Consumer. J Marketing 36: 23-31. 